\title{
ANTITUMOR ACTIVITY OF ECHINOSPORIN
}

\author{
MAKoto Morimoto and RyoJi Imai \\ Pharmaceutical Research Laboratory, Kyowa Hakko Kogyo Co., Ltd., \\ 1188 Shimotogari, Nagaizumi-cho, Sunto-gun, Shizuoka-ken, Japan
}

(Received for publication September 12, 1984)

\begin{abstract}
Echinosporin isolated from a Streptomyces culture showed antitumor activity against rodent tumor models such as leukemia P388, P388/VCR, and fibrosarcoma Meth 1. It was marginally active against melanoma B16 and sarcoma 180. It was not active against Lewis lung carcinoma and xenograft MX-1. It inhibited the colony formation of HeLa $\mathrm{S}_{3}$ cells with a wide shoulder at low dose ranges. DNA, RNA, and protein synthesis were inhibited by echinosporin. It depressed WBC with nadir on day 3 , but the recovery to the normal level after echinosporin injection was more rapid than that after mitomycin $\mathrm{C}$.
\end{abstract}

Echinosporin with a novel carbon skelton was isolated from the culture broth of Streptomyces echinosporus MK-213. ${ }^{1,2)}$ This antibiotic exhibited weak antibacterial activities against Gram-positive and Gram-negative bacteria. The MICs were $100 \mu \mathrm{g} / \mathrm{ml}$ against Proteus vulgaris, Salmonella typhosa, Shigella sonnei and higher than $200 \mu \mathrm{g} / \mathrm{ml}$ against Escherichia coli and Bacillus subtilis.

This paper describes the antitumor activity against various murine tumors, the acute toxicity, the bone marrow toxicity, and growth inhibitory activity on tumor cells in vitro and the macromolecule synthesis of $\mathrm{HeLa} \mathrm{S}_{3}$ cells.

\section{Materials and Methods}

\section{Chemicals}

Echinosporin was prepared according to the method of OKACHI et al. ${ }^{1)}$ Mitomycin C (Kyowa Hakko Kogyo Co., Ltd.) and vincristine (Sigma Chemicals, U.S.A.) were used as reference antitumor agents. $\left[{ }^{3} \mathrm{H}\right]$ Thymidine $\left(\left[\right.\right.$ methyl $\left.-{ }^{3} \mathrm{H}\right]$ thymidine $\left.55 \mathrm{Ci} / \mathrm{mmol}\right),\left[{ }^{3} \mathrm{H}\right]$ uridine $\left(\left[5-{ }^{3} \mathrm{H}\right]\right.$ uridine $\left.25 \mathrm{Ci} / \mathrm{mmol}\right)$ and $\left[{ }^{3} \mathrm{H}\right] l$ leucine $\left(\mathrm{L}-\left[4,5-{ }^{3} \mathrm{H}\right] \mathrm{leucine} 156 \mathrm{Ci} / \mathrm{mmol}\right)$ were obtained from the Radiochemical Center Amersham (U.K.).

\section{Antitumor Activity}

Antitumor activity against leukemia P388, sarcoma 180 and melanoma B16 was studied as described in the previous report. ${ }^{3)}$ Fibrosarcoma Meth 1 which had originally been induced by 3-methylcholanthrene in BALB/c mice in our laboratory has been maintained in ascites form in BALB/C mice. ${ }^{4)}$

For the antitumor test, $1 \times 10^{6}$ cells of Meth 1 were inoculated ip into $\mathrm{CDF}_{1}$ mice $(20 \sim 22 \mathrm{~g})$. Leukemia P388 resistant to vincristine (P 388/VCR) was kindly donated by Dr. M. INABA, Cancer Chemotherapy Center (Tokyo). P388/VCR cells $\left(1 \times 10^{6} / \mathrm{CDF}\right.$ mouse) were inoculated ip. Human xenograft MX-1 was donated by the Cancer Chemotherapy Center (Tokyo). Solid tumor $\left(2^{3} \mathrm{~mm}^{3}\right)$ was inoculated sc into BALB/c nu/nu mice by trocar and drugs were injected on day 14 when the tumor volume was about $125 \mathrm{~mm}^{3}$. The tumor volume was calculated by the formula represented in the NCI protocol for screening. ${ }^{5)}$

\section{Bone Marrow Toxicity}

For the peripheral white blood cell count, $20 \mu 1$ of supraorbital venous blood was mixed with $9.98 \mathrm{ml}$ of Cellkit-7 solution (Toa Medical Electro Co., Ltd.) and counted by microcell counter (Toa Medical Electro Co., Ltd.) after lysis of erythrocytes with saponin S (Toa Medical Electro Co., Ltd.). Differential counts of white blood cells were performed on Wright-stained smear of pretreatment blood 
Table 1. Effect of echinosporin on leukemia P388.

\begin{tabular}{|c|c|c|c|c|}
\hline & $\begin{array}{c}\text { Dose } \\
\text { (mg/kg/day) }\end{array}$ & Schedule ${ }^{a)}$ & MST (days) $\left.{ }^{b}\right)$ & $\operatorname{ILS}(\%)^{c)}$ \\
\hline Control & & day 1 & $9.4 \pm 0.5$ & - \\
\hline \multirow[t]{10}{*}{ Echinosporin } & 80 & day 1 & $10.2 \pm 6.7$ & 9 \\
\hline & 60 & day 1 & $15.4 \pm 1.3$ & 64 \\
\hline & 40 & day 1 & $14.8 \pm 1.1$ & 57 \\
\hline & 20 & day 1 & $12.6 \pm 0.9$ & 47 \\
\hline & 10 & day 10 & $10.8 \pm 1.8$ & 15 \\
\hline & 30 & day $1 \sim 5$ & $7.8 \pm 1.3$ & 0 \\
\hline & 20 & day $1 \sim 5$ & $12.6 \pm 0.5$ & 40 \\
\hline & 10 & day $1 \sim 5$ & $12.4 \pm 0.9$ & 38 \\
\hline & 5 & day $1 \sim 5$ & $11.2 \pm 0.4$ & 24 \\
\hline & 2.5 & day $1 \sim 5$ & $9.4 \pm 0.5$ & 4 \\
\hline \multirow[t]{3}{*}{ Mitomycin $\mathrm{C}$} & 6 & day 1 & $26.2 \pm 7.4$ & 179 \\
\hline & 4 & day 1 & $16.6 \pm 0.9$ & 77 \\
\hline & 1 & day $1 \sim 5$ & $22.0 \pm 3.9$ & 144 \\
\hline
\end{tabular}

a) Leukemia P388 ( $1 \times 10^{6}$ cells) was inoculated ip in $\mathrm{CDF}_{1}$ mice on day 0 and drugs were injected ip on day 1 or once a day for 5 days from day 1 .

b) Mean survival days $\pm \mathrm{SD}$.

c) Increased life-span.

Each group consisted of 5 mice.

Table 2. Effect of echinosporin on P388 and P388/ VCR.

\begin{tabular}{lccc}
\hline & \multirow{2}{*}{\begin{tabular}{c} 
Dose \\
\cline { 3 - 4 }
\end{tabular}} & \multicolumn{2}{c}{$\mathrm{ILS}^{(\mathrm{mg} / \mathrm{kg})^{\mathrm{b})}}$} \\
\cline { 3 - 4 } & & P388 & P388/VCR \\
\hline Echinosporin & 80 & 12 & 9 \\
& 60 & 64 & 45 \\
& 40 & 50 & 103 \\
Vincristine & 20 & 33 & 23 \\
& 10 & $\mathrm{NT}$ & 19 \\
& 4 & -47 & -2 \\
& 2 & 34 & 2 \\
& 1 & 41 & -2 \\
& 0.5 & 41 & 5 \\
& 0.25 & 29 & 9 \\
\hline
\end{tabular}

a) Leukemia P388/VCR or P388 $\left(1 \times 10^{8}\right.$ cells $)$ was inoculated ip on day 0 and echinosporin or vincristine was injected ip on day 1.

b) Increased life-span.

Each group consisted of 5 mice.

NT: Not tested on day 4 after treatment which was found to be the nadir of WBC depression.

\section{In Vitro Studies}

HeLa $\mathrm{S}_{3}$ cells used in this study were kindly donated by Dr. K. KurodA, National Institute of Genetics (Mishima) and maintained in Eagle minimum essential medium (MEM) (Nissui Seiyaku Co., Ltd.) supplemented with $10 \%$ fetal bovine serum(FBS, Grand Island Biological Company, New York, U.S.A.) and glutamine (10 mM). HeLa $\mathrm{S}_{3}$ cells $(150$ cells $/ 5 \mathrm{ml}$ ) were plated in plastic dishes ( $9 \mathrm{~cm}$ diameter) (NUNC Co., Ltd., Denmark) and drugs were added 3 hours after plating. The treatment of cells with drugs was carried out by adding a small amount of phosphate buffer saline solution (PBS) (GIBCO, N.Y., U.S.A.) of the drug into the culture. After 30 minutes incubation with drugs, the cultures, including untreated control, were rinsed twice and then fed with fresh and prewarmed culture medium for further incubation. After 10 days, the number of colonies was counted and the average of 3 plates at each drug concentration was calculated. The plating efficiency of the untreated control culture varied from $80 \sim 90 \%$ in each experiment.

The precursor incorporation into the TCA insoluble fraction was measured by pulse-labeling of HeLa $\mathrm{S}_{3}$ cells with $\left[{ }^{3} \mathrm{H}\right]$ thymidine $(0.5 \mu \mathrm{Ci} / \mathrm{ml}),\left[{ }^{3} \mathrm{H}\right]$ uridine $(0.5 \mu \mathrm{Ci} / \mathrm{ml})$ or $\left[{ }^{3} \mathrm{H}\right]$ leucine $(1.5 \mu \mathrm{Ci} / \mathrm{ml})$ at every hour from 60 minutes after adding the drugs at $37^{\circ} \mathrm{C}$. Immediately after incubation with the radioactive precursors for 1 hour, the medium containing the radioactive precursor was removed by aspiration. The adherent cells were washed with $5 \%$ trichloroacetic acid (TCA) for 30 minutes and then with ethanol for 10 minutes. The dried cell residues were dissolved in $1 \mathrm{ml}$ of $0.5 \mathrm{~N} \mathrm{NH}_{4} \mathrm{OH}$ and the 
Table 3. Effect of echinosporin on fibrosarcoma Meth 1.

\begin{tabular}{|c|c|c|c|c|c|}
\hline & $\begin{array}{c}\text { Dose } \\
(\mathrm{mg} / \mathrm{kg} / \text { day })\end{array}$ & Schedule $^{\text {a) }}$ & $\begin{array}{c}\text { MST } \\
\text { (days) }\end{array}$ & $\begin{array}{l}\text { ILS }{ }^{b)} \\
(\%)\end{array}$ & $\begin{array}{l}\text { 60-dayc) } \\
\text { survivors }\end{array}$ \\
\hline Control & & & $16.9 \pm 3.0$ & & \\
\hline \multirow[t]{12}{*}{ Echinosporin } & 80 & day 1 & $2.6 \pm 0.5$ & - & \\
\hline & 60 & day 1 & $36.3 \pm 7.8$ & 118 & \\
\hline & 40 & day 1 & $38.0 \pm 7$ & 125 & \\
\hline & 30 & day 1 & $39.8 \pm 11.9$ & 136 & $1 / 5$ \\
\hline & 20 & day 1 & $36.2 \pm 14.0$ & 114 & $1 / 5$ \\
\hline & 10 & day 1 & $33.6 \pm 16.9$ & 99 & \\
\hline & 30 & day $1 \sim 5$ & $7.8 \pm 1.8$ & 0 & \\
\hline & 20 & day $1 \sim 5$ & $47.2 \pm 11.1$ & 179 & $1 / 5$ \\
\hline & 10 & day $1 \sim 5$ & $57.6 \pm 5.4$ & 241 & $4 / 5$ \\
\hline & 5 & day $1 \sim 5$ & $21.8 \pm 7.8$ & 29 & \\
\hline & 2.5 & day $1 \sim 5$ & $23.8 \pm 10.2$ & 41 & \\
\hline & 1.25 & day $1 \sim 5$ & $25.6 \pm 13.2$ & 51 & \\
\hline Mitomycin C & 6 & day 1 & $71.4 \pm 13.2$ & 311 & \\
\hline
\end{tabular}

a) Fibrosarcoma Meth 1 cells $\left(10^{6}\right.$ cells/mouse) were inoculated ip on day 0 and drugs were injected ip on day 1.

b) ILS $(\%)$ were calculated including 60 -day survivors and the survival times of 60 -day survivors was defined as 60 days.

c) Each group consisted of 5 mice.

Table 4. Antitumor activity of echinosporin on murine experimental tumor system.

\begin{tabular}{|c|c|c|c|c|c|}
\hline Tumor & System & Schedule & $\begin{array}{l}\text { Optimal dose } \\
(\mathrm{mg} / \mathrm{kg} / \text { day) }\end{array}$ & $\mathrm{T} / \mathrm{C} \times 100$ & $\begin{array}{c}\text { Day of } \\
\text { evaluation }\end{array}$ \\
\hline \multirow[t]{3}{*}{ P388 } & ip-ip & day 1 & 60 & 164 & \\
\hline & ip-ip & day $1 \sim 5$ & 20 & 140 & \\
\hline & iv-iv & day 1 & 60 & 117 & \\
\hline P388/VCR leukemia & ip-ip & day 1 & 40 & 203 & \\
\hline EL-4 leukemia & ip-ip & day 1 & 50 & 113 & \\
\hline \multirow[t]{2}{*}{ Meth 1 fibrosarcoma } & ip-ip & day 1 & 30 & 236 & \\
\hline & ip-ip & day $1 \sim 5$ & 10 & 341 & \\
\hline B16 melanoma & ip-ip & day 1 & 50 & 132 & \\
\hline \multirow[t]{3}{*}{ Sarcoma 180} & sc-ip & day 1 & 60 & 85 & day 7 \\
\hline & sc-iv & day 1 & 60 & 90 & day 7 \\
\hline & sc-iv & day $1 \sim 5$ & 50 & 46 & day 7 \\
\hline Lewis lung carcinoma & sc-iv & day 1 & 20 & 57 & day 10 \\
\hline MX-1 & sc-ip & day $14 \sim 20$ & 40 & 72 & day 35 \\
\hline
\end{tabular}

radioactivity of the aliquot was counted by a liquid scintillation counter.

KB cells which was kindly donated by Dr. S. Tsukagoshi, Cancer Chemotherapy Center (Tokyo) were cultured in MEM supplemented with $10 \%$ FBS and $10 \mathrm{~mm}$ glutamine. Cells $\left(10^{5} \mathrm{cells} / \mathrm{ml}\right)$ were plated in multidish 24 wells (NVNC) and the drugs in PBS solution were added on day 1. After incubation with drugs for 3 days, the culture media were discarded and washed with $\mathrm{Ca}^{++}$free-PBS. Single cells were obtained by the incubation of $0.05 \%$ trypsin and $0.02 \mathrm{~mm}$ EDTA. The number of cells were counted by microcell counter.

\section{Results and Discussion}

\section{Antitumor Activity}

As shown in Table 1, echinosporin was effective against leukemia P388 implanted ip by a single injec- 
Fig. 1. Effect of echinosporin on the peripheral white blood cell counts of normal $d d Y$ mice.

* $P<0.05, * * P<0.01$. (Student's t test)

- Echinosporin; $60 \mathrm{mg} / \mathrm{kg} \times 1 \mathrm{iv,} \mathbf{\Delta}-\mathbf{\Delta}$ echinosporin; $60 \mathrm{mg} / \mathrm{kg} \times 1 \mathrm{ip}$, mitomycin $\mathrm{C}$; $6 \mathrm{mg} / \mathrm{kg} \times 1 \mathrm{iv}$.

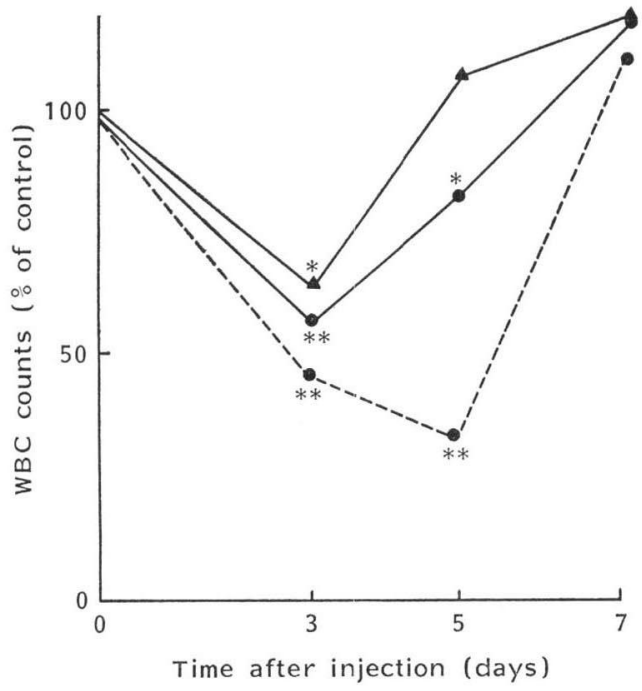

Fig. 2. Cell killing activity of echinosporin on HeLa $\mathrm{S}_{3}$ cells. $\mathrm{D}_{0}=9.8 \mu \mathrm{g} / \mathrm{ml} \quad(\mathrm{n}=4.7)$.

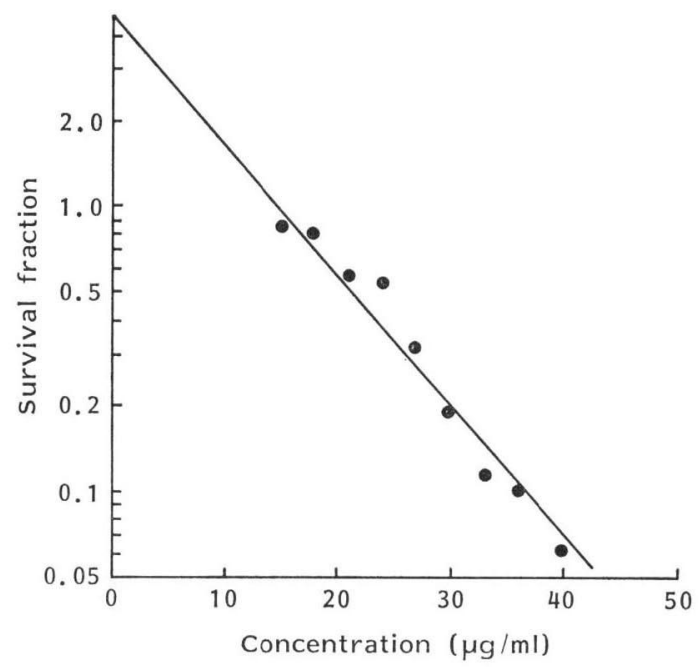

Fig. 3. Effect of echinosporin on the growth of $\mathrm{KB}$ cells.

$\mathrm{KB}$ cells $\left(10^{5}\right.$ cells) were cultured for 24 hours at $37^{\circ} \mathrm{C}$ in MEM supplemented with calf serum. After addition of drugs, cells were incubated for another 72 hours. After decantation of culture fluid and washing, single cells were obtained by trypsin-EDTA and the numbers of cells were counted. Percentages of treated group to untreated group were calculated.

- Echinosporin, $\mathrm{O}$ mitomycin C.

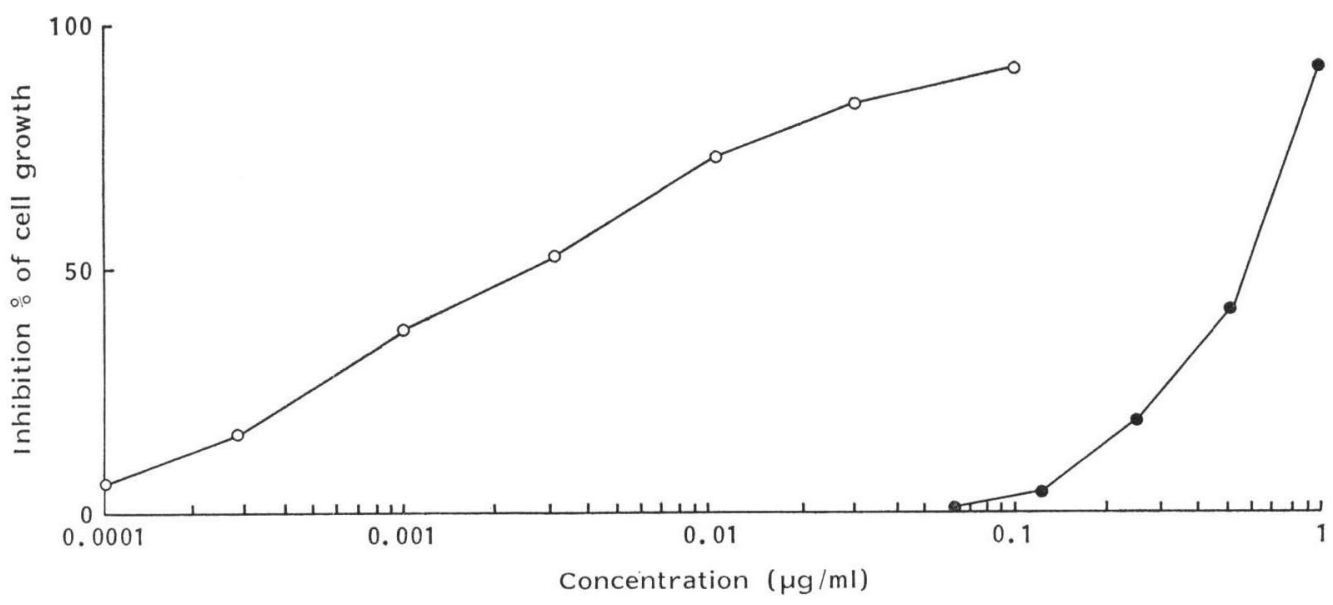

tion on day 1 , or by successive administration once a day for 5 days. The optimal dose of a single administration was $60 \mathrm{mg} / \mathrm{kg}$ and gave ILS of $64 \%$. With successive administration, it gave ILS of $40 \%$ at an optimal dose of $20 \mathrm{mg} / \mathrm{kg} /$ day. Significant activity was exhibited against mice bearing P388/ VCR inoculated ip. The maximum ILS against P388/VCR was $103 \%$ at a dose of $40 \mathrm{mg} / \mathrm{kg}$. It was more effective against P388/VCR than against P388 and showed the collateral sensitivity to P388/VCR 
Fig. 4. Effect of echinosporin on colony formation of $\mathrm{HeLa} \mathrm{S}_{3}$ cells and macromolecule synthesis.

$\mathrm{HeLa} \mathrm{S}_{3}$ cells (200 cells) were cultured in the dish (5 cm diameter) in MEM supplemented with $10 \%$ FBS and treated with $1(\Delta)$ or 5 (踾) $\mu \mathrm{g}$ of echinosporin for the period shown in Fig. 4 . Cells were washed with fresh medium and the numbers of colonies were counted after 10 days.

The radioactive precursors were added at the indicated time after addition of $1(\mathbf{A}), 5(\mathbf{d}), 10$ (3) $\mu \mathrm{g}$ of echinosporin and incubated for 1 hour. TCA were added and the radioactivity incorporated into TCA insoluble fraction was measured. \% radioactivity of treated group to untreated control was determined.

Cell killing activity $\left[{ }^{3} \mathrm{H}\right]$ Thymidine

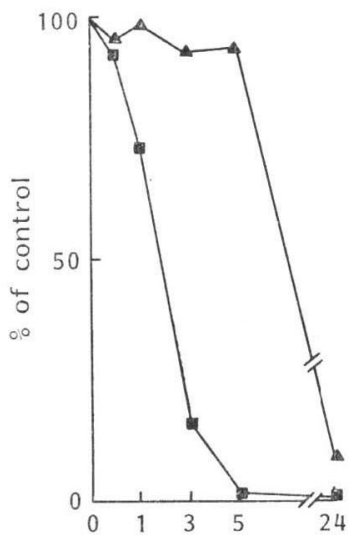

$\left[{ }^{3} \mathrm{H}\right]$ Uridine

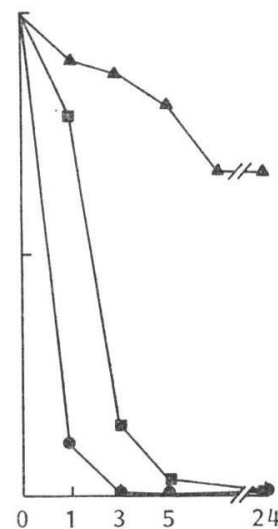

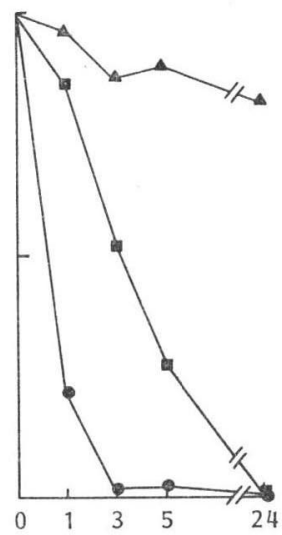

Exposure time (hours) $\left[{ }^{3} \mathrm{H}\right]$ Leucine

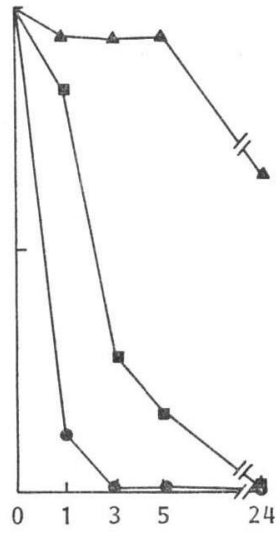

(Table 2). Echinosporin gave a significant prolongation of the life-span against mice bearing Meth 1 . It gave $80 \%$ of 60 day survivors by a consecutive 5 days administration at a dose of $10 \mathrm{mg} / \mathrm{kg} / \mathrm{day}$. The activity of echinosporin against Meth 1 was superior to that of mitomycin C (Table 3 ).

Echinosporin was only marginally active against ascitic tumor of B16 melanoma and gave 32\% ILS at a single dose of $50 \mathrm{mg} / \mathrm{kg}$. It was less effective than mitomycin C which gave $93 \%$ ILS with a single injection (Table 4).

Echinosporin was not active by a single ip administration on day 1 against the solid tumor of sarcoma 180. It was marginally active by iv and po 5 consecutive daily injections from day 1 and gave $\mathrm{T} / \mathrm{C}$ of 0.46 and 0.41 respectively (Table 4). Echinosporin did not give a prolongation of the life-span of $\mathrm{BDF}_{1}$ mice bearing EL-4 (10 cells/mouse, ip). For sc implanted Lewis lung carcinoma, it did not show the inhibition of the tumor growth or prolongation of life-span. The growth of MX-1 was not inhibited with $\mathrm{T} / \mathrm{C}$ of 0.70 by a 7 consecutive iv administration (Table 4).

\section{Bone Marrow Toxicity}

At the ip and iv dose of echinosporin of $60 \mathrm{mg} / \mathrm{kg}$, the WBC nadir occurred on day 3 post-treatment and was $63 \%$ and $56 \%$ of control, respectively. These values were not statistically significant from $56 \%$ of control WBC obtained with $6 \mathrm{mg} / \mathrm{kg}$ of mitomycin $\mathrm{C}$ (almost equal to dose of $\mathrm{LD}_{10}$ ). But the WBC nadir occurred on day 5 after treatment with $33 \%$ of control at the iv dose of mitomycin C (Fig. 1). The depression of WBC count by echinosporin recovered more rapidly than that by mitomycin $\mathrm{C}$. The WBC differential count revealed the damage to lymphocytes.

\section{Effect on Cells In Vitro}

Cell killing activity of echinosporin was shown on HeLa $\mathrm{S}_{3}$ cells. The cells exposed for 30 minutes 
showed a dose-dependent exponential survival curve with a wide shoulder at low concentration range. The mean lethal dose $\left(\mathrm{D}_{0}\right.$, the dose to give $37 \%$ survival) was $9.8 \mu \mathrm{g} / \mathrm{ml}$ and $\mathrm{n}$ (extrapolating value of exponential portion of dose survival curve) was 4.7 (Fig. 2). This might indicate that the DNA damage induced by echinosporin could be repaired effectively from sublethal damage.

The growth of $\mathrm{KB}$ cells was inhibited in vitro by echinosporin. $\mathrm{IC}_{50}$ (concentration which gave $50 \%$ cell number of control) of echinosporin was $0.62 \mu \mathrm{g} / \mathrm{ml}$ at 72 -hour exposure and was more than 200 -fold higher than that of mitomycin C (Fig. 3). The dose dependent growth inhibition curve of echinosporin was different from that of mitomycin $\mathrm{C}$. The ratio of $\mathrm{IC}_{90} / \mathrm{IC}_{50}$ was 2 and more than 10 for echinosporin and mitomycin $C$, respectively.

\section{Effect on Macromolecule Synthesis}

Echinosporin inhibited $\left[{ }^{3} \mathrm{H}\right]$ thymidine, $\left[{ }^{3} \mathrm{H}\right]$ uridine and $\left[{ }^{3} \mathrm{H}\right]$ leucine incorporation into TCA insoluble fraction dose-dependently, $\left[{ }^{3} \mathrm{H}\right]$ thymidine incorporation was relatively more significantly inhibited than the other two radioactive precursors incorporation at $5 \mu \mathrm{g} / \mathrm{ml}$. But there was no significant difference in the inhibitory activity of echinosporin on the incorporation of them into TCA insoluble fraction (Fig. 4). DNA synthesis might be primarily inhibited, but further studies for the mechanism of action is needed.

The blood urea nitrogen value of serum of mice injected a single dose of $60 \mathrm{mg} / \mathrm{kg}$ (ip) did not deviate from that of control mice (unpublished data).

While the antitumor activity and spectrum of echinosporin were not superior to those of antitumor antibiotics which are now in clinical use, the uniqueness of the structure and the solubility are interesting and need further studies.

\section{References}

1) Sato, T.; I. Kawamoto, T. OKa \& R. Oкасhi: A new antibiotic echinosporin (XK-213) - Producing organism, isolation and characterization. J. Antibiotics 35:266 271, 1982

2) Iida, T.; N. Hirayama \& K. Shirahata: Structure of echinosporin. Abstracts Papers, 44th Ann. Meeting of Japan Chemical Soc., IE-18, pp. 403, 1981

3) Morimoto, M.; S. Окиво, F. Tоміта \& H. Marumo: Gilvocarcins, new antitumor antibiotics. 3. Antitumor activity. J. Antibiotics 34: 701 707, 1981

4) Gomi, K.; M. MоRiмото \& K. Nомото: Cytotoxic T-cell-mediated antitumor effect of levamisole against murine syngeneia fibrosarcoma. Cancer Res. 42: 4197 4202, 1982

5) Geran, R. I.; N. H. Greenberg, M. M. Macdonald, A. M. Schumacher \& B. J. Аbbott: Protocols for screening chemical agents and natural products against animal tumor and other biological systems. Cancer Chemother. Rep. Part 3: 1 100, 1972 